$235,12-19-75=$

LA-6112-MS

Informal Report

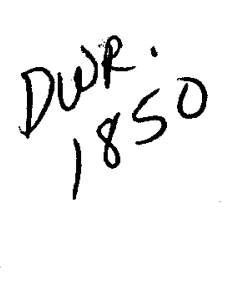

UC-66

Reporting Date: September 1975 Issued: November 1975

\title{
Geophysical Logging in \\ Los Alamos Scientific Laboratory \\ Geothermal Test Hole No. 2
}

by

F. G. West

P. R. Kintzinger

A. W. Laughlin

scientific laboratory

of the University of California

LOS ALAMOS, NEW MEXICO 87545

2

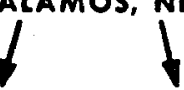

An Affirmative Action/Equal Opportunity Emṕloyer 


\section{DISCLAIMER}

This report was prepared as an account of work sponsored by an agency of the United States Government. Neither the United States Government nor any agency Thereof, nor any of their employees, makes any warranty, express or implied, or assumes any legal liability or responsibility for the accuracy, completeness, or usefulness of any information, apparatus, product, or process disclosed, or represents that its use would not infringe privately owned rights. Reference herein to any specific commercial product, process, or service by trade name, trademark, manufacturer, or otherwise does not necessarily constitute or imply its endorsement, recommendation, or favoring by the United States Government or any agency thereof. The views and opinions of authors expressed herein do not necessarily state or reflect those of the United States Government or any agency thereof. 


\section{DISCLAIMER}

Portions of this document may be illegible in electronic image products. Images are produced from the best available original document. 
In the interest of prompt distribution, this report was not edited by the Technical Information staff.

Printed in the United States of America. Aroilable trom

National Technical Information Service

U S Department of Commerce

$\mathbf{5 2 3 5}$ Port Royal Road

Springtield VA 22151

Price: Printed Copy \&4.00 Microtiche \$2.25 
GEOPHYSICAL LOGGING IN LOS ALAMOS SCIENTTFIC LABORATORY

GEOTHERMAL TEST HOLE NO. 2

by

F. G. West, P, R. Kintzinger, and A. W. Laughlin

ABSTRACT

The Los Alamos Scientiflc Laboratory drilled Geothermal Test Hole No. 2 to a depth of $2932 \mathrm{~m}$ (9619 ft) as a part of the "Dry Hot Rock" Geothermal Energy Profect. The hole encountered $732 \mathrm{~m}(2402 \mathrm{ft})$ of volcantc and sedimentary rocks before penetrating $2200 \mathrm{~m}(7217 \mathrm{ft})$ of crystalline rock. Varlous geophysical logs were run, the most useful for the purposes of the profect being the full-wave sonic logs, as an Indication of relative competence of the rock, and the spectral gamaray 108 , to Indicate general rock type.

\section{INTRODUCTION}

Geothermal Test Hole No. 2 (GT-2) was drilled as a part of the fleld program of the Los Alamos Scientific Laboratory's (LASL) Dry Hot Rock Geothermal Energy Source Demonstration Project. The project thesis is simply that by drilling deeply enough one can find rock at a temperature which would be useful as an energy source. The depth of drilling required 1s primarily a function of the temperature needed for a particular application, the $10 \mathrm{cal}$ geothermal gradient, and the efficiency of the thermal extraction process. Except when relatively low-intensity heat Is useful, the temperature requirement is usually met only at depths where rock permeabilities are generally thought to be quite low, such that in most frames of reference the holes would be termed "dry."

The low thermal conductivity of rock requires exposure of a substantial surface area if a meaningful amount of thermal energy is to be extracted. (The assumption of low hydraulic permeability of course precludes development by the circulation of fluld through the rock.) Hydraulfe fracturing of the rock is suggested as one method of developing the contact area necessary for a thermal mining operation.

GT-2 was drilled to a depth of $2932 \mathrm{~m}(9619 \mathrm{ft})^{*}$ using drilling procedures and equipment typlcal of

* Hole depths given throughout this report are measured downward from the Kelly bushing on the drilling rig, which was $3.7 \mathrm{~m}$ above the ground surface at the wellhead. hard-rock drilling. Coring was performed using a core bit silghtly modified from that developed for the Deep Sea Drilling Project (JOIDES) and by the use of standard diamond core bits. The details of the drilling project as summarized by Pettitt ${ }^{1,2}$ are shown in Appendix A.

\section{LOCATION}

The project area is located on Fenton Hill, $3 \mathrm{~km}$ (2 miles) northwest of La Cueva, Sandoval County, New Mexico. The site location is as follows: NE 1/4, Sec 13, T19N, R2E NMPM. The land-surface elevation is $2648.7 \mathrm{~m}(8690 \mathrm{ft})$.

GEOLOGY

The profect site is approximately $3 \mathrm{~km}$ (2 miles) west of the ring fault zone associated with the collapse of the Valles Caldera. Faults associated with the Rto Grande rift valley are thought to be the locus of former volcanic activity in the area. ${ }^{3}$ One group of faults, the Jemez Springs fault zone, is some $5 \mathrm{~km}$ ( 3.1 miles) southeast of the site. The Jemez-Nacimiento Mountains area has been a structurally active area to varying degrees since Precambrian time. Evidence of structural activity after the last eruption from the Valles Caldera is seen along the Jemez Springs fault zone, the closest known fault being the Virgin Canyon fault. 4 Some postvolcantsm uplift may have taken place west of the Rio de Las Vacas in the Nacimiento Mountains. Dri11ing information and geophysical logs suggest that 


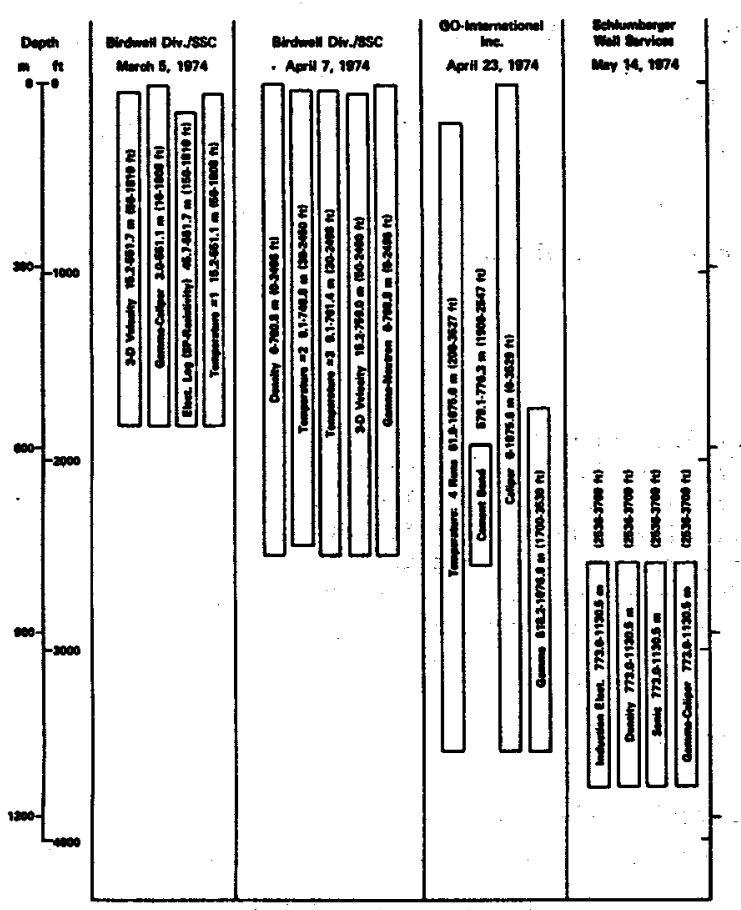

Fig. 1. Diagnostic logging services performed in GT-2 from March through May 1974.

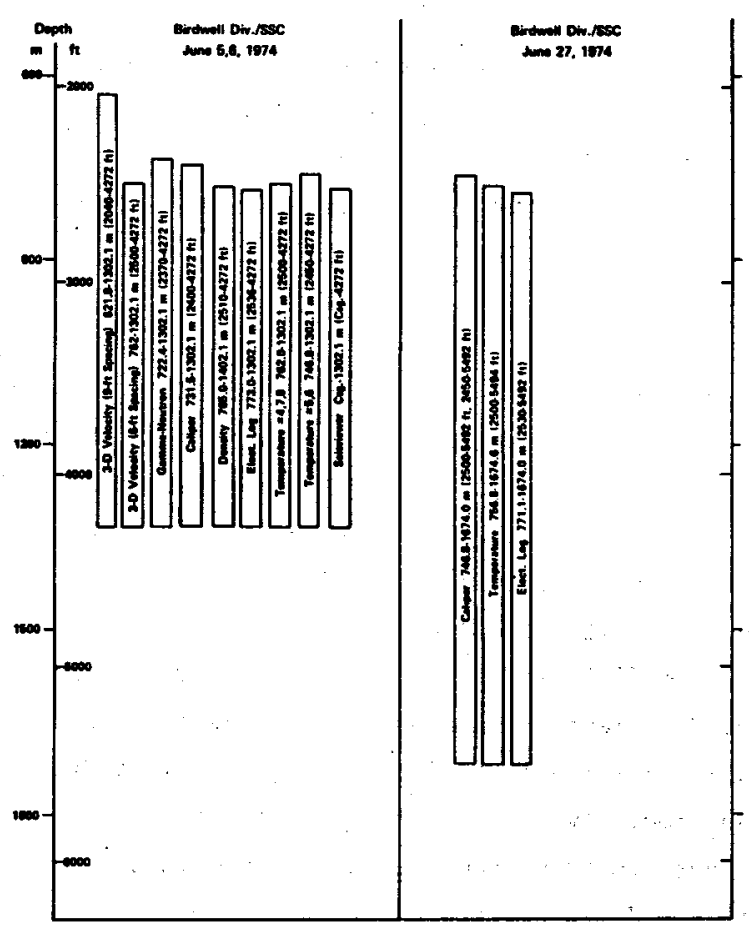

F1g. 2. Diagnostic logging services performed in GT-2 during June 1974.

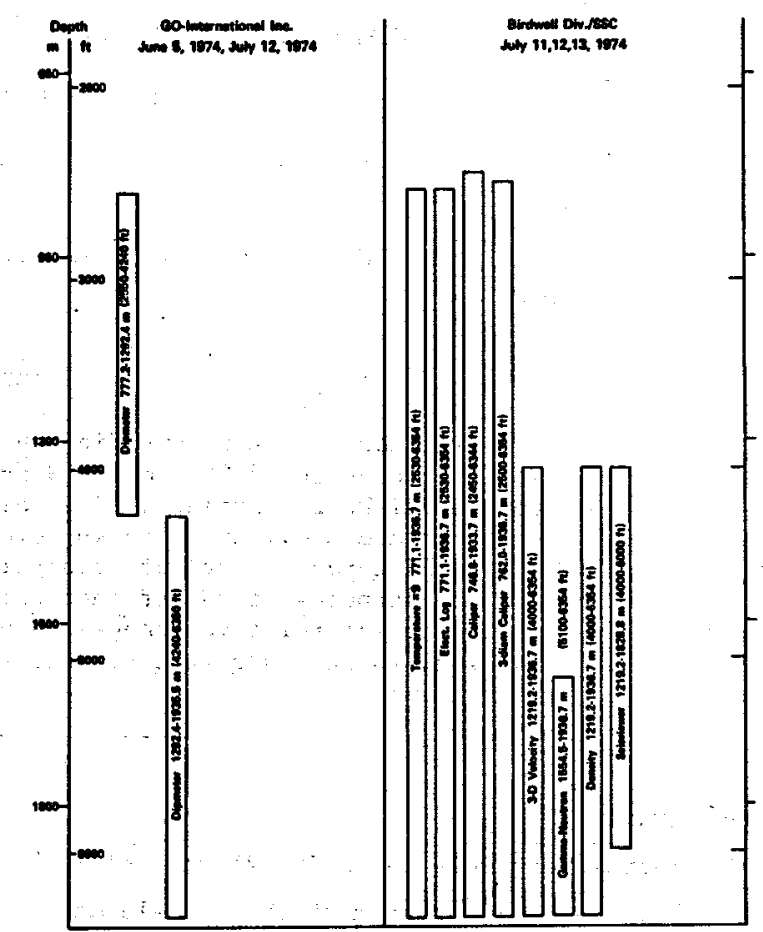

F1g. 3. Diagnostic logging services performed in GT-2 during June and July 1974.

fracture zones with unknown displacement were encountered in GT-2.

The hole penetrated some $137 \mathrm{~m}$ (449 ft) of volcantcs, $238 \mathrm{~m}$ ( $780 \mathrm{ft}$ ) of Permian red beds, and $355 \mathrm{~m}$ $(1165 \mathrm{ft})$ of Pennsylvanian-Mississippian shales and limestones, before encountering granite at $732 \mathrm{~m}$ (2402 ft). 5 The crystalline Precambrian rocks include granites, granodiorites, monzonites, biotite schist, and amphibolite. The textures ranged from fine to coarse grained and the colors from pink to black.

GEOPHYSICAL LOGGING

The logging program for GT-2 was drafted in anticipation of the information which would be necessary or usefui to the project. Practical considerations occastonally caused the deletion or addition of particular logs. The logs run and the coverage of each $10 \mathrm{~g}$ are shown in Figs. 1-5. Four comercial logging services were used at various t1mes. The Water Resources Branch of the U. S. Geological Survey ran a short suite of logs with plans to $\log$ the completed hole at a later date. Thermal recovery with time was measured at the bottom of the 


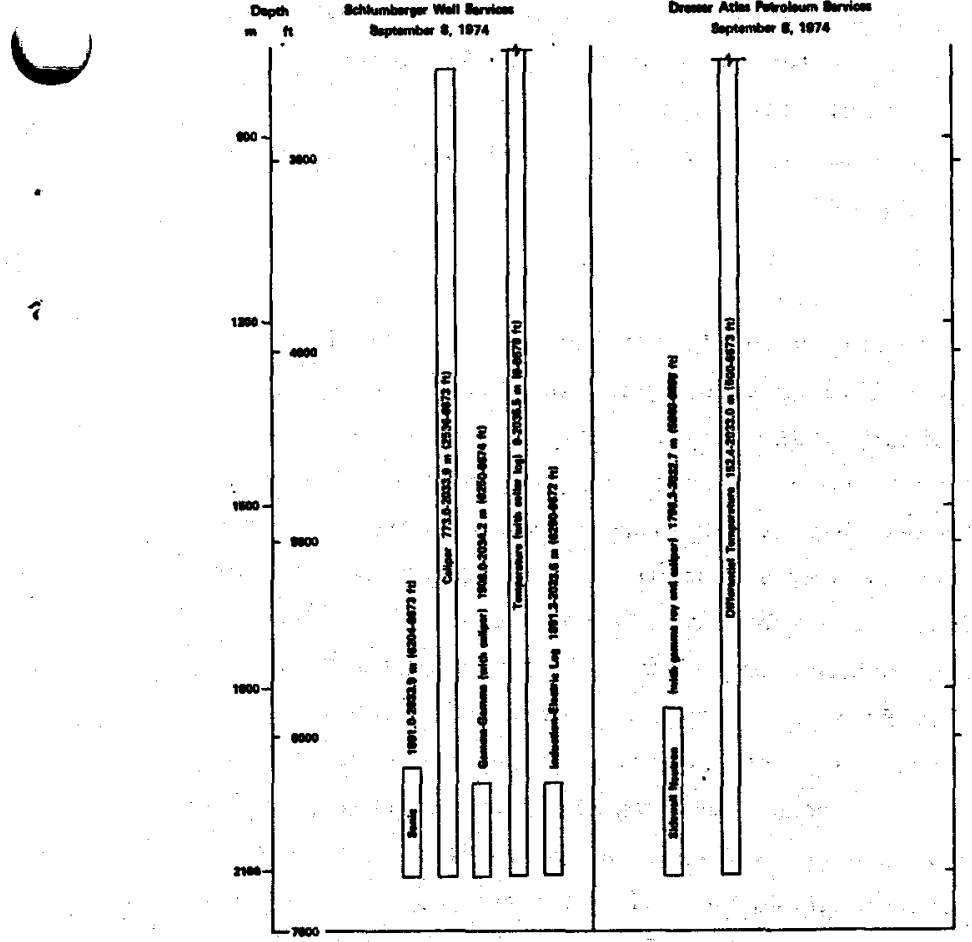

Fig. 4. Diagnostic logging services performed in GT-2 on September 8, 1974.

hole during drilling breaks by LASL personnel. 6 The logging of the sedimentary section of the hole is of local interest; however, the logging of a substantial section of crystalline basement rock is probably of general interest. To expedite the release of the logs, only their qualitative aspects will be discussed in this report. Physical property type logs are given in Appendix B. The 1tthologic description which accompanies the geophystcal logs was prepared by William D. Purtymun, Dan J. Miles, and Andrea C. Eddy from the drili cuttings and petrographic examination of the cores. The spectral gamma $10 \mathrm{~g}$ was also used to Identify rock-type transition levels. The International Union of Geological Sciences rock-type classification and nomenclature which were used for this $10 \mathrm{~g}$ supersede those used by Pettitt. ${ }^{1,2}$

\section{SEDIMENTARY-SECTION LOGS}

Lost-circulation and hole-sloughing problems limited the logging depth and suite of logs that could be taken before an Intermediate string of casing was set. Alternating ledges and washout zones produced such an Irregular hole that several of the logs were of rather limited usefulness. Nuclear logs were run after the sedimentary section of the hole was cased.

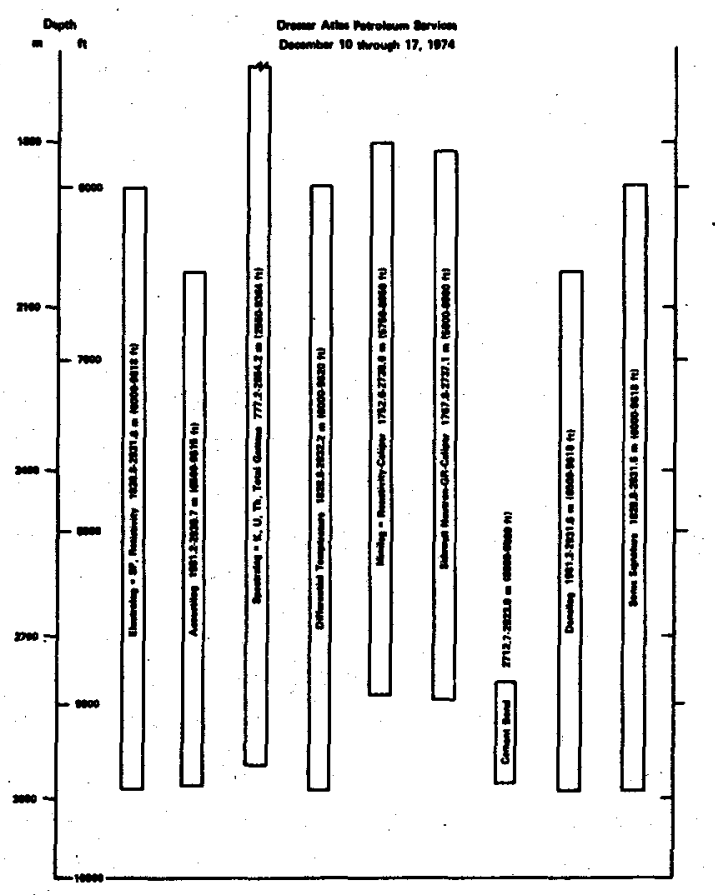

Fig. 5. Diagnostic logging services performed in GT-2 during December 1974 .

\section{CRYSTALLINE-SECTION LOGS}

The drill-rate log, although not a geophysical $\log$ per se, does indicate the relative hardness and competence of the rocks. Of course such factors as the drill-bit condition, bit-rotation rate and the weight on the bit, all of which were varied in attempts to find an optimum drilling condition, affect the drilling rates shown. However, the drill-rate $10 g$ correlates reasonably well with the geophysical logs, and thus can be used as a real-time indicator of zones that are of interest to the profect.

Reaction of the rocks to the drilling process, primarily to flutd circulation, is indicated by the calfper $\log$ (which measures hole dlameter). This gives another indication of relative rock hardness or competence. Major zones of hole enlargement correlate with zones of Intense natural fracturing as inferred from other logs. Rock type does not have the marked Influence that is normal on logs in sedimentary rock, but some effect is noticed-for Instance when the mica content of the rock increases. GT-2 does not fit the concept that drill holes in crystalline rock are "gun barrel" holes. The three-diameter (six-arm) caliper log was helpful 
in determining the dip of fracture-zone washouts encountered. Principal use of the caliper logs has been for the selection of sites for seating the packers required to seal off a section of hole for tests to determine rock permeability ${ }^{7}$ and for the hydraulic fracturing experiments.

\section{ELECTRIC LOGS}

The various electric logs run were useful in accomplishing the primary project purpose of logging, that 1s, in locating zones of permeability, which were usually found to be coincident with zones of intense fracturing. The electric logs run were the selfpotential, 16-in.-normal, 64-in.-normal, lateral, wall-resistivity, induction, and the dip log.

Few of the physical situations are present in crystalline rocks that generate the electric selfpotentials found in sedimentary rocks. Occasionally at permeable fracture zones small potentials were measured which were probably due to electrokinetic effects. The largest potentials found were probably due to electrochemical effects associated with mafic rocks.

The resistivity logs, although somewhat subdued in an environment of highly resistive crystalline rocks, were effective as indicators of permeable zones. The resistivities measured by even the longest electrode spacings of the lateral $\log$ are probably somewhat less than the true formation resistivities due to the shunting effect of a conductive drill mud in relation to an extremely high formation resistivity. Generally the longer electrode spacings indicated higher resistivities then the shorter electrode spacings. This effect, which might normally indicate invasion of the formation by drilling fluids is not confirmed by the shallow depth of investigation of wall-resistivity logs. Fracture zones give some indication of drill-flutd invasion on the wallresistivity logs as interpreted from mud cake buildup in these zones. Focused-current type devices may be somewhat more effective for measurement of true formation resistivity in this particular situation. Induction-log records, although giving indication of some fractures in the crystalline rock, were offscale for most of the $\log$ due to high crystallinerock resistivity.

The electric formation-dip-orientation 108 appeared to give good data; however, overlapping of logging runs did not produce particularly good agreement, nor was the correlation with the assumed standard, the selsviewer $10 \mathrm{~g}$, good. The electric dip log tended to give low values of dip relative to the selsviewer log.

\section{- BULK-DENSITY LOG}

Porosity determination is one of the main uses of the bulk-density or scattered gama-ray $\log$ in sedimentary drill holes. Although crystalline basement rocks do not generally have the range of bulk densities that is exhibited by sedimentary rocks, the density 108 may be useful in crystalline rocks as an indicator of lithology. The relative mafic content of the rock may be inferred from the departure of the $\log$ from values typical for granite rock. ${ }^{8-10}$ Confirmation of the validity of the procedure is found in correlations with the self-potential, resistivity, neutron, and spectral gamma logs. The sonic $10 g$ cannot always be used for confirmation as can be seen in the mafic zone from 1692 to 1725 in (5550 to $5660 \mathrm{ft}$ ), where the bulk density increases but the sonic velocity does not increase as one might expect. ${ }^{11}$ Since mafic-type rocks have higher electron densities than does the medium generally used to calibrate density logging tools, some correction must be made to the logged values in a mafic rock zone. Otherwise the bulk-density log correlates reasonably well with densities determined from cores. 12

\section{NEUTRON LOG}

The $\log$ which appears to have the least potential In crystalline basement rocks is the neutron $\log$. The primary use of the $\log$ is usually for estimation of fluid filled porosity. Crystalline rocks generally have a rather limited range of porosities, except possibly in fracture zones.

The neutron logs were not without some character, as for Instance the zone at $1178 \mathrm{~m}(3865 \mathrm{ft})$. This zone shows a high-in-bulk density with an attendant increase in sonic velocity as indicated by the blip on the full-wave sonic $10 \mathrm{~g}$, but the neutron $10 \mathrm{~g}$ would seem to indicate an increase In porosity which usually Indicates a decrease in sonic velocity. Since the density and sonic logs indicate reduced porosity, the neutron $\log 1 s$ probably indicating the presence of a material with a high cross section to neutrons, quite likely a mafic type of intrusion. The zone of 
mafic rocks, from 1692 to $1725 \mathrm{~m}$ (5550 to $5660 \mathrm{ft}$ ) shows a slight apparent Increase in porosity, a similar Increase in density, but in this case without a confirmation on the sonic $\log$ of increased velocity, probably indicating a material with a high neutron cross section and high electron density.

\section{SPECTRAL-GAMMA LOG}

Certain logs are relied on more than others to define the 1ithology in sedimentary rocks; for crystalline basement rocks the 11thology log is possibly the spectral ganma $10 \mathrm{~g}$. This $10 \mathrm{~g}$ consists of four records, one for total gama activity and one each for thorfum, uranium, and potassium. Thorium is determined by measuring the activity of the 2.62MeV daughter Isotope ${ }^{208} \mathrm{~T} 1$. Uranium 18 determined. from the $1.76-\mathrm{MeV}^{214} \mathrm{BI}$ gamma activity and potassium from the $1.46-\mathrm{MeV}{ }^{40} \mathrm{~K}$ peak. Sensitivities for the three elements were potassium, $0.42 \%$ per chart division; uranium, 2:8 ppm per chart division, and thorium, $6.8 \mathrm{ppm}$ per chart division.

Thorlum showed the least amount of character, heving only minor excursions from the $6.8 \mathrm{ppm}$ line, except below the depth of $2591 \mathrm{~m}(8500 \mathrm{ft})$ where a shift to about $11 \mathrm{ppm}$ occurs. Positive anomalies in the thorium content are often accompanied by increases in the potassium content and occasionally in the uranium content. The thorium content varies from 2 ppm to 23 ppm.

The uranium content of ten exhibits a high either in, or close to, fracture zones. Because uranfum is more mobile than thorfum, a depth plot of the rat1o of activities of thorium to uranium accentuates fracture zones. The uranium content varies from almost zero to $32 \mathrm{ppm}$.

Potassium content appears to give the most information on 1ithology. The hornblende-blotite schists and amphibolites are easily recognized by low, uniform, total-gama activitles of about 4000 +1000 counts. The low count rate in these rocks is due largely to a relatively low potassium content, which ranged from 1,1 to $1.8 \%$. The urantum content varied from almost zero up to $2.8 \mathrm{ppm}$ and the thorium content varied from $1: 8$ to $4.1 \mathrm{ppm}$. The mafic-rock radioactivity anomaly can also be correlated with a high electric self-potentiel, a slight low in apparent porosity (neutron), and a high-in-bulk density.
It does not appear 11kely that felsic granitold and gneissic rocks can be distinguished by using the spectral log. The activities of the felsic granitold rocks are usually higher than those of the mafic rocks, but the activities are extremely variable, often with sharp peaks. The variable activities reflect compositional variations in these rocks which may be elther sharp or gradual.

\section{FULL-WAVE SONIC LOG}

One of the most useful logs for profect purposes 1s the full-wave sonic log. In contrast to the sonic travel-time $\log$ which displays only the time of first arrival, the full-wave log displays the full-wave train beginning with the pressure wave. This $10 \mathrm{~g}$ gives one an immediate feeling for the character of the rock. Fracture zones that are merely suspected on other logs jump out on the full-wave sonfc log, for instance, the zones at $914 \mathrm{~m}$ ( $(3000 \mathrm{ft})$ and $1829 \mathrm{~m}$ $(6000 \mathrm{ft})$. The sonic velocity decreases in fracture zones as a result of an increase in porosity. The relative Intensity of fracturing in zone can be estimated from the decrease in velocities, or from the change in the $v$-pressure/v-shear ratio. ${ }^{13,14}$. Even small fractures can be seen in the " $x$ " pattern In the wave train between the arrival of the primary wave and the shear wave. ${ }^{15}$ Some zones do not exhibit this effect as much as other zones. Based on Information from cores, zones which do not exhibit the effect probably have complete healing or cementing: of the fractures. Slight, or a general increase in velocity due to Increased loading with increased depth is not observè in these logs as has been suggested from laboratory investigations. 16 The fullwave sonic $\log$ in confunction with the density $10 \mathrm{~g}$ was used to compute the In situ elastic constants of the rock. The constants derived from geophysical logs were in reasonable agreement with those measured In the laboratory when the volume sampled and the altered environment of cores are considered.

\section{SETSVIEWER LOG}

The selsviewer (borehole televlewer, USGS), a sonar type of borehole-wall scanning tool, is quite valuable to the "dry hot rock" project because of Its capability for delineating fractures directly and not merely by inference. ${ }^{17}$ The orlentation of natural fractures may give some insight to previous stress 
fields. Induced-fracture orientation may be controlled by the remnint of stress fields which caused the original natural fractures, or. simply by the planes of weakness created by previous fracturing (if a hydrostatic stress field is assumed to be present).

The selsviewer $\log$ also detected several zones In the hole which exhibited the grooved helical feature known as "rifling." This feature may appear for Intervals of $3 \mathrm{~m}$ (10 ft) to sometimes over $30 \mathrm{~m} \mathrm{(100)}$ ft), starting and ending abruptly. Rifling is probably related primarily to drilling dynamics, and it is of Interest to note the occurrence in "hard" rock. The caliper $\log$ and to some extent the density $10 \mathrm{~g}$ respond to the rifling with a scalloped appearance, as seen at a depth of 1387 to $1454 \mathrm{~m}$ (4550 to 4770 ft).

\section{TEMPERATURE LOG}

Fluctuations in the apparent geothermal gradient indicated by the temperature logs decreased with increased depth. Pertubations on the $10 \mathrm{~g}$ usually coincide with washouts caused by the less competent rock in fracture zones. The relative permeability of a fracture zone is probably indicated by the amount of temperature reversal or pertubation and the interval of the hole in which the effect is observed. The gradient in the hole varied from 50 to $60^{\circ} \mathrm{C} / \mathrm{km}$. The extrapolated equilibrium bottomhole temperature was $197^{\circ} \mathrm{C}\left(386.6^{\circ} \mathrm{F}\right)$.

\section{CONCLUSIONS}

Although the response of most of the geophysical logs in an environment of crystalline rocks was not altogether ordinary, still the logs were most useful. Interpretation of geophysical logs of crystalline rocks may often require a review of the physical principles on which the $\log$ is based. ${ }^{18,19}$ It appears that a quantitative interpretation of the logs will require an experience or empirical base not unlike that developed for logging in sedimentary rocks. The single most useful $\log$ for project purposes was the full-wave sonic log. The lithologic log in crystalline rock is the spectral gamma log. Of course a full suite of geophysical logs is the best assurance of obtaining the necessary data for any project.

\section{REFERENCES}

1. R. A. Pettitt, "Planning, Drilling, and Logging of Geothermal Test Hole GT-2, Phase I," Los Alamos Scientific Laboratory report LA-5819-PR (January 1975).

2. R. A. Pettitt, "Testing, Driliing, and Logging of Geothermal Test Hole GT-2, Phase II," Los Alamos Sclentific Laboratory report LA-5897-PR (March 1975).

3. R. L. Smith and R. A. Balley, "The Bandelfer Tuff: A Study of Ash-Flow Eruption Cycles from Zoned Magma Chambers," Bul1. Volcanologique 29, 83-104 (1966).

4. D. B. Slemmons, "Fault Activity and Selsmicity Near the Los Alamos Scientific Laboratory Geothermal Test site, Jemez Mountains, New Mexico," Los Alamos Scientific Laboratory report LA-5911MS (Apri1 1975).

5. W. D. Purtymun, F. G. West, and R. A. Pettit, "Geology of Geothermal Test Hole GT-2, Fenton H111 Site, July 1974," Los Alamos Scientific Laboratory report LA-5780-MS (November 1974).

6. J. N. Albright, "Temperature Measurements in the Precambrian Section of Geothermal Test Hole No. 2," Los Alamos Scientific Laboratory report LA-6022-MS (August 1975).

7. F. G. West, P. R. Kintzinger, and W. D. Purtymun, "Hydrologic Testing Geothermal Test Hole No. 2," Los Alamos Scientific Laboratory report LA-6017MS (August 1975).

8. V. Rzhevsky and G. Novik, The Physics of Rocks (M.I.R. Publishers, Moscow, 1971), p. 47.

9. V. Vankova and V. Kropacek, "Gamma-Ray Absorption and Chemical Composttion of Neovolcanic Rocks," Studia Geophy. et Geod. 18, 173-185 (1974).

10. V. Vankova, "Gamma-Ray Absorption in Granodiorite," Studia Geophy. et Geod. 18, 367-369 (1974).

11. F. Press, "Seismic Velocities" in Handbook of Physical Constants, S. P. Clark, Jr., Ed. (Geo1. Soc. Am., 1966), p. 205.

12. J-C. Roegiers, Los Alamos Scientific Laboratory personal communication, December 1974.

13. V. Schenk and Z. Schenkova, "Stress Wave Velocity and Crack System of a Medium," Geophy. Prosp. 22, 710-721. (1974).

14. R. L. Geyer and J. I. Myung, "The '3-D' Velocity Logs: A Tool for In Situ Determination of the Elastic Moduli of Rocks," 12th Annual Symposium on Rock Mechantcs, Rólla, Missour1, November 16, 1970 .

15. J. M. Bird, "An Explanation of the '3-D' Acoustical Logging System for the Exploration Geophysicist," Mexican Geophysical Society Convention, Monterrey, Mexico, October 26-30, 1965. 
16. G. Simons and A. Nur, "Granttes: Relation of Properties In S1tu to Laboratory Measurements," Science 162, 789-791 (1968).

17. J. Zemanek, B. E. Glenn, L. J. Norton, and R. L. Caldwel1, "Formation Evaluation by Inspection with Borehole Televiewer," Geophy, 35, 254269 (1970).
18. J. H. Scott and B. L. TAbbets, "Wel1-Logging Techniques for Mineral Deposit Evaluation: A Review," U. S. Bureau of Mines I. C. 8627 , 45 pp (1975).

19. W. S. Keys and L. M. MacCary, "Application of Borehole Geophysics to Water-Resource Invest1gations," Techniques of Water-Resource Investigations of the U. S. Geological Survey, Bk. 2, Ch. E-1, 126 pp. (1971). 
APPENDIX A

SUMMARY OF DRILLING, CASING, CEMENTING AND GEOLOGIC DATA
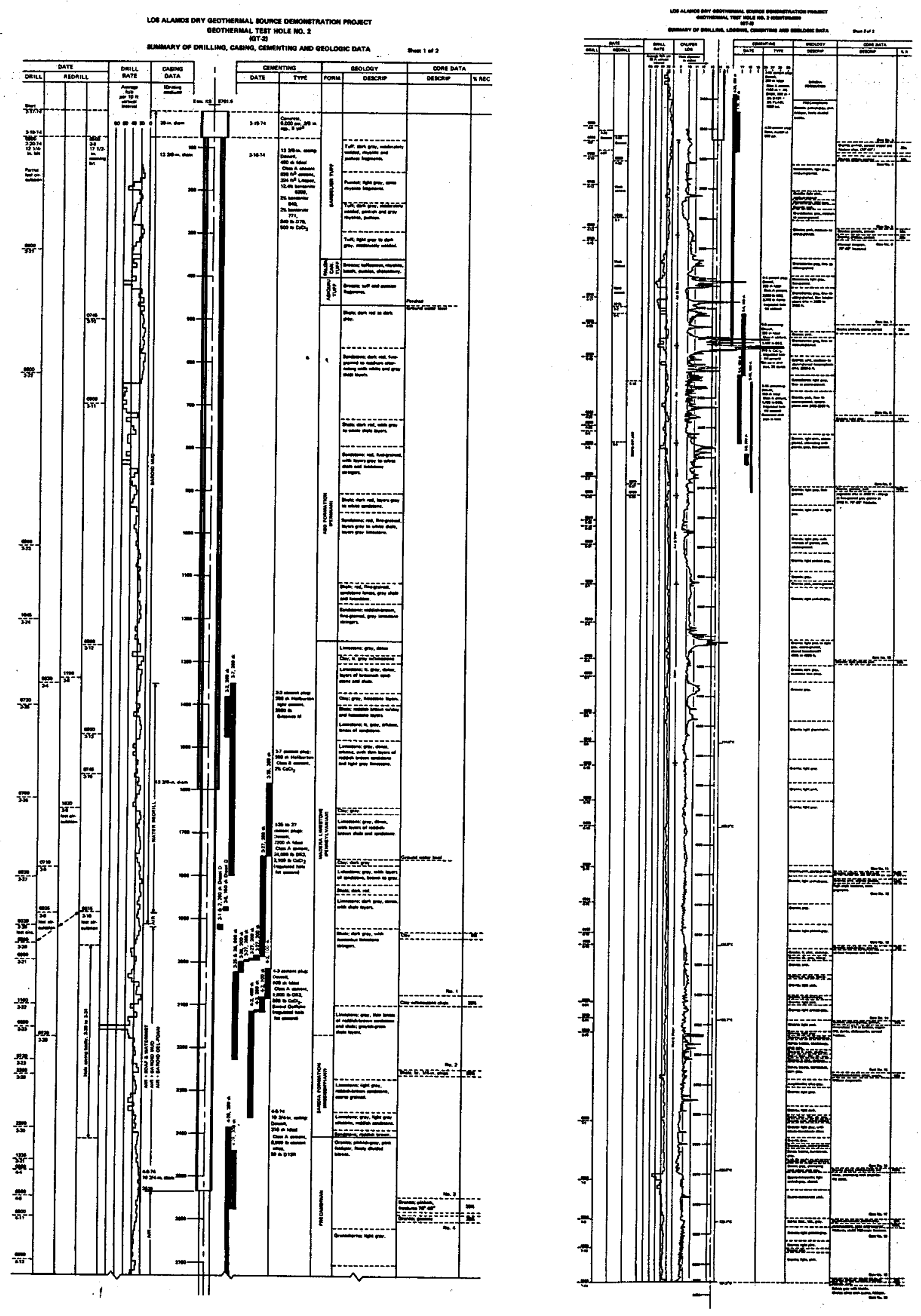


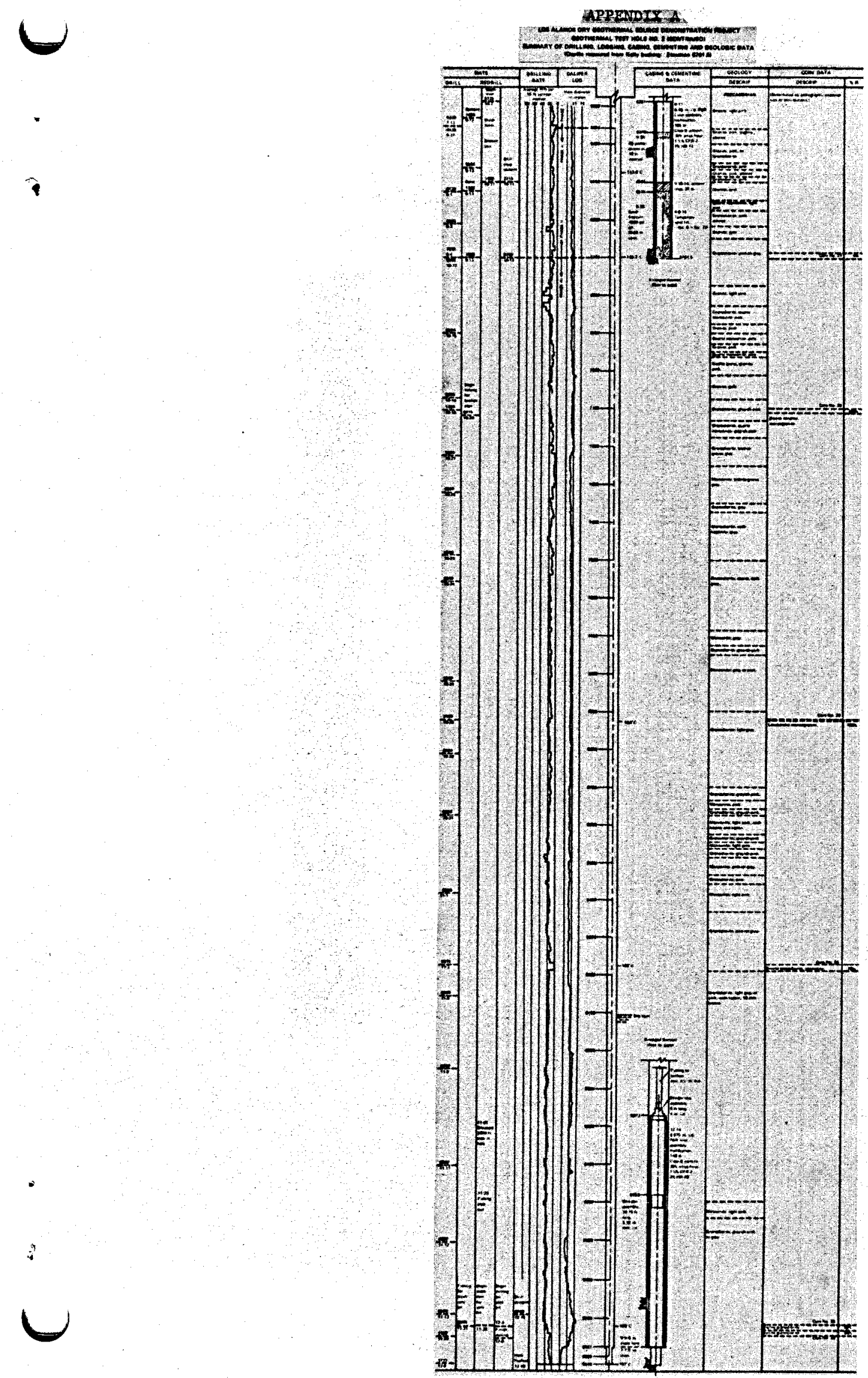


APPENDTX B

LOS ALAMOS SCIENTIFIC LABORATORY

GEOTHERMAL TEST HOLE N2 2

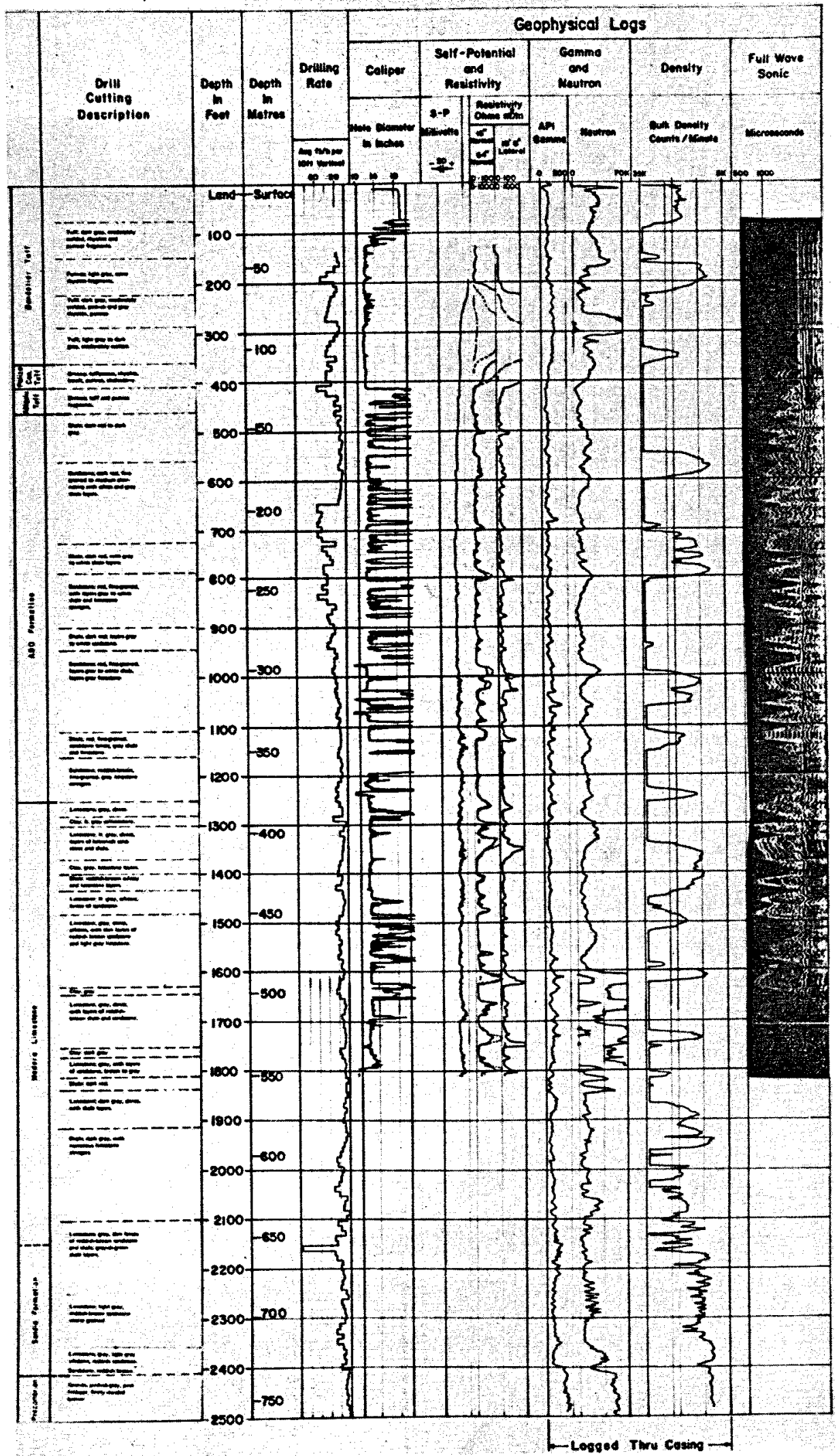




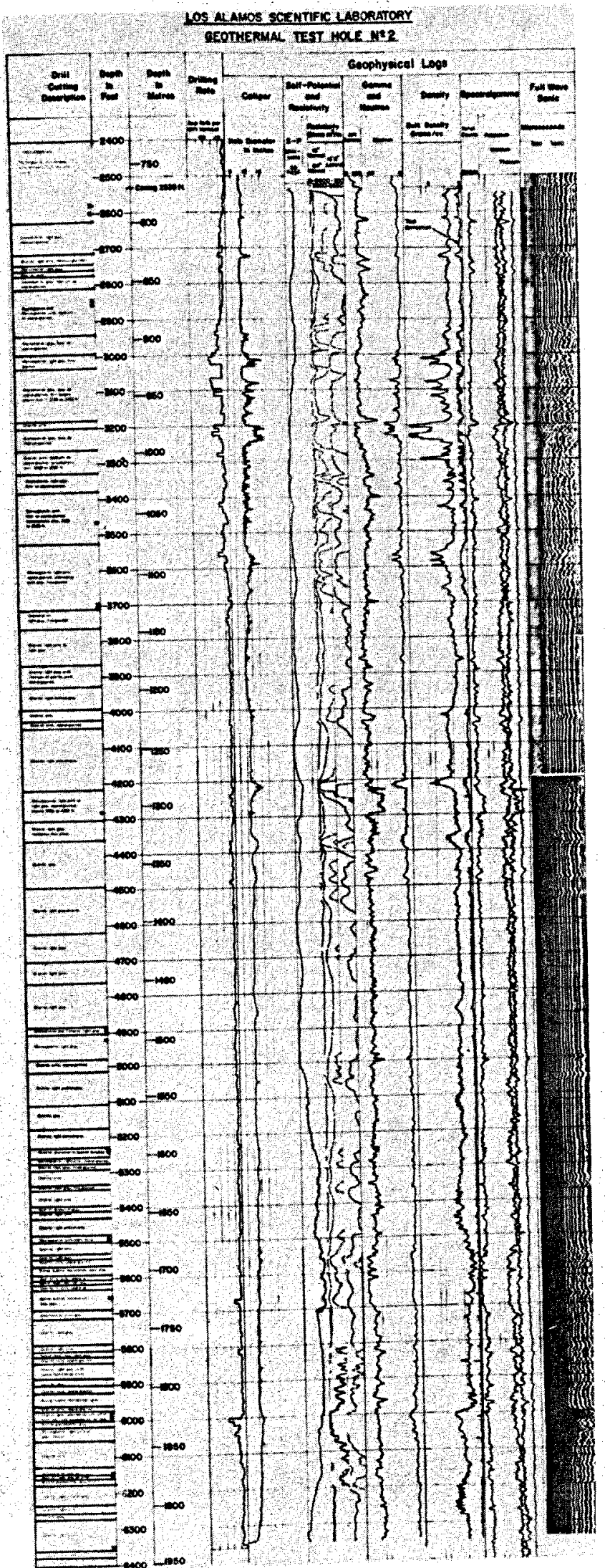




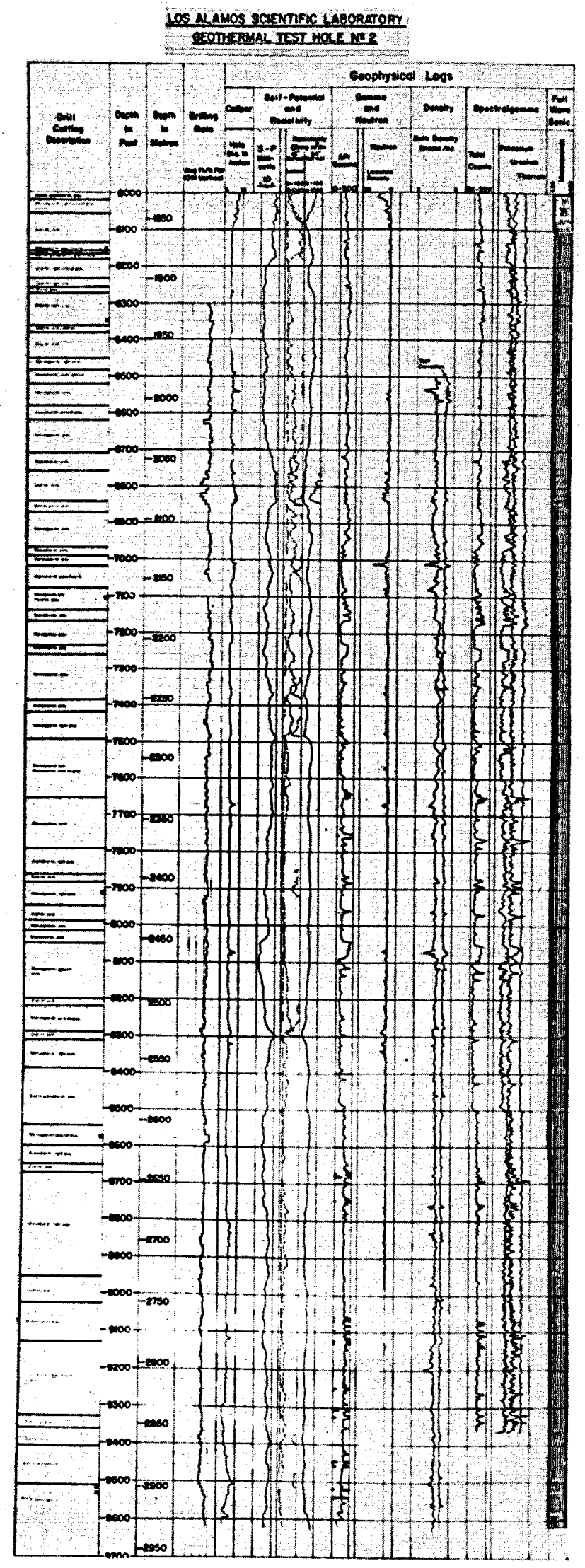

